\title{
主流に垂直な二次噴流を伴う超音速乱流場の数值計算*
}

\author{
户田和 之*1, 山本誠*2

\section{Computation of Supersonic Turbulent Flowfield with Secondary Jet normal to Freestream}

\author{
Kazuyuki TODA and Makoto YAMAMOTO
}

\begin{abstract}
Steady flowfields resulting from slot injection at the surface of a flat plate in a freestream with a Mach number of 3.75 and unit Reynolds number of $1.65 \times 10^{7} \mathrm{~m}^{-1}$ are simulated, using the compress. ible mass-averaged Navier Stokes equations and five typical turbulence models. The flowfields with various total pressure ratios of injection to freestream are computed, and comparisons are made with experimental data in terms of the surface total pressure distribution, the length of the upstream separation region, and the height of the Mach surface (i. e. penetration height). Two characteristics of model performances are clarified. Though the upstream separation length and the penetration height are differently predicted by each turbulence model, the correlations between them are nearly same. A Reynolds stress model can reproduce the upstream separation region more reasonably than a $k-\varepsilon$ model does, especially for high injection pressure cases.
\end{abstract}

Key Words: Computational Fluid Dynamics, Supersonic Flow, Turbulent Flow, Jet, Turbulence Model

\section{1. 緒}

21 世紀初頭に実用化が予定され，近年開発が盛んに 行われている超音速有翼飛しょう体の推進機として, スクラムジェットエンジン開発の必要性が高まってき ている。この研究にはいまだ多くの技術的課題が残さ れており，その中でも超音速流れ状態にある燃焼器内 での然料と空気の混合が大きな問題のー・として举げら れている，また，スクラムジェットェンジンは，その 使用条件が臬高度，極超音速領域であるため，作動条 件に合せた実験が困難であり，数傎解析による流れ場 構造の解明が，その開発に重要な役割を担うであるう と期待されている。本研究は，このような背景を踏ま え, スクラムジェットエンジン開発の基礎研究として, 超音速流れ中に吹出した二次噴流回りの流れ場に対す る乱流モデルの検証，ならびに流れ場構造の検討を行 うものである。

超音速の主流に対して垂直にスロットノズルより二 次流れガ久を噴出させた場合の特徵的流れ場の概略図 を図 1 に示寸、スロットノズルより曊出された二次流

* 拍稿受付 1997 作 4 月 18 日

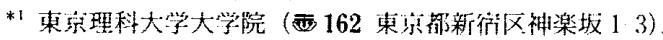

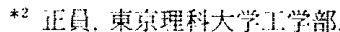

れは，主流との圧力差により主流中で急速に膨張し， Mach Disk 抢よびBarrrel Shock と呼ばれる衝撃波 面を形成しこれらが主流を遮る形となって強い Bow Shock が形成され，この衝撃波と境界首の干渉 によって境界層はく離が生じる，スロット前方での境 界屡はく離は，超音速の主流に対して一...次流れを噴出 させた場命の特徵的現象の一つであり，このはく離に 伴って, 境界展のはく離点付近より Separation Shock を生じ, Bow Shock が十分に成長している場 合には衝撃波/衝揧波干涉を引き起こす。また，ス口 ットノズル下流側では，超音速流れの巻込みによる Expansion Fanや, 境界厤の再付着による Recompression Shockが生じる.この流れ場に対する研究

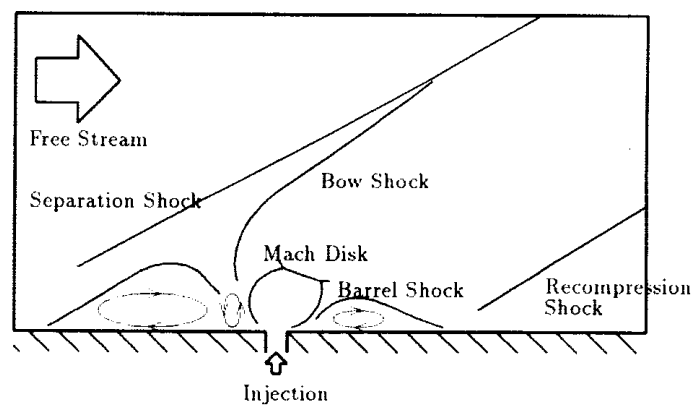

Fig. 1 Schematic of the flow field 
は, Zukoshi-Spaid ${ }^{(1),(2)}$, Schtz $~_{(3)}$, Hawk-Amik ${ }^{(4)}$,

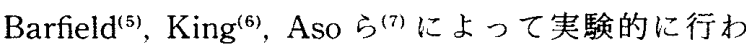
れており, 流れ場の特徴がレイノルズ数, 主流マッハ 数, 境界層厚さ, スロットノズル幅, 全压比(二次流れ ガス全压の主流全圧に対する比，扔よび二次流れガ ス分子量などによって支配されることが知られてい る。

本研究では, 高レイノルズ数形乱流モデルとして, 非压縮性分野に扔いて最も広く使用されている $k-\varepsilon$ モデル，高い再現性を得ている応力方程式モデル，さ らに乱れの壁面溸近挙動に着目したそれらの低レイノ ルズ数形モデル(計 5 種類)を用いた数值計算を実施 し，壁面全压，貫通高さ，インゼクション前方干涉領 域という観点より，主流に垂直な二次噴流を伴う超音 速乱流場に対する乱流モデルの検証を行う。また，得 られた数值計算結果から，本流れ場の構造について検 討が加えられる。

\section{2. 乱 流モ デル}

近年のコンピュータの急速な発達に伴い,さまざま な压縮性乱流場の数值解析が行われているが, 多数の 反復が必要な設計計算に対しては，その計算負荷の少 なさより，いまだ 0 方程式モデルである BaldwinLomax モデルなどを使用するのが一般的である。し かし、この種のモデルには長さスケールの定義に関し て原理上の問題があり，衝撃波位置やはく離領域の大 きさを必ずしも正しく表せないなどの問題も明らかと なっている，最近では，輸送方程式から長さスケール を求める 2 方程式モデルが长縮性乱流場の計算におい ても用いられ始め，压縮性モデルに対するさまざまな 提案も行われているが, さほど顕著な改善が見られて いないのが現状である。さらに，本研究で対象とする ような複雑な流れ場に対しては，乱流モデルの検証は ほとんど行われていない.

そこで本研究では，非圧縮性分野で高い信頼性を得

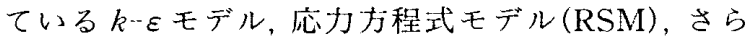
に卡れらの低レイノルズ数形モデルを用いて計算を行 い，モデルの予測性能を検討する，使用した5種類の

Table 1 Turbulence model

\begin{tabular}{|l|c|c|}
\hline & $k-\varepsilon$ Model & Reynolds Stress Model \\
\hline $\begin{array}{l}\text { High Reynolds } \\
\text { Number Type }\end{array}$ & $\begin{array}{c}\text { Launder-Spalding } \\
(1974)\end{array}$ & $\begin{array}{c}\text { Gibson-Launder } \\
(1978)\end{array}$ \\
\hline $\begin{array}{l}\text { Low Reynolds } \\
\text { Number Type }\end{array}$ & $\begin{array}{c}\text { Lam-Bremhorst } \\
(1981)\end{array}$ & $\begin{array}{c}\text { Shima } \\
\text { Shimada-Nagano } \\
(1996)\end{array}$ \\
\hline
\end{tabular}

乱流モデルを表 1 に示す．以下，使用したモデルの詳 練について記すこととする。

$2 \cdot 1 k \boldsymbol{k}-\boldsymbol{\varepsilon}$ モテル 2 方程式モデルである $k-\varepsilon モ$ デルは, 乱れのエネルギー $k$ とその散逸率 $\varepsilon$ を輸送 方程式から求め, これらより渦粘性を決定するもので, 渦粘性の仮定によりレイノルズ応力はつねに拡散的に 作用する。このため，計算スキームが安定であり，非 圧縮性乱流の分野では工学上最も広く用いられてい る.

ブジネスクの渦粘性仮説により，レイノルズ応力成 分はひずみ速度 $S_{i j}\left[=\partial \tilde{u}_{i} / \partial x_{j}+\partial \tilde{u}_{j} / \partial x_{i}\right.$ $\left.-\left(2 \partial \tilde{u}_{k} / 3 \partial x_{k}\right) \cdot \delta_{i j}\right]$ を用い次の式で表される.

$$
\begin{aligned}
& -\overline{\rho u_{i}^{\prime \prime} u_{j}^{\prime \prime}}=\mu_{t} S_{i j}-\frac{2}{3} \bar{\rho} k \delta_{i j} \\
& \mu_{t}=C_{\mu} f_{\mu} \bar{\rho} \frac{k^{2}}{\varepsilon}, C_{\mu}=0.09 . .
\end{aligned}
$$

ここで $\mu_{t}$ は渦粘性， $\tilde{u}_{i}, u_{i}^{\prime \prime}$ はそれぞれFavre平均を 施した平均速度成分と，変動速度成分である。

$k$ および $\varepsilon$ の輸送方程式は，形式的に

$$
\begin{aligned}
& \frac{D(\bar{\rho} k)}{D t}=(\text { Pro. })_{k}+(\text { Dif. })_{k}+(\text { Dis. })_{k} \\
& \frac{D(\bar{\rho} \varepsilon)}{D t}=(\text { Pro. })_{\varepsilon}+(\text { Dif. })_{\varepsilon}+(\text { Dis. })_{\varepsilon}
\end{aligned}
$$

と表され，冬項は以下のようにモデル化される.

$$
\begin{aligned}
& (\text { Pro. })_{k}=\left(\mu_{t} S_{i j}-\frac{2}{3} \bar{\rho} k \delta_{i j}\right) \frac{\partial \tilde{u}_{j}}{\partial x_{i}} \\
& (\text { Dif. })_{k}=\frac{\partial}{\partial x_{i}}\left\{\left(\mu+\frac{\mu_{t}}{\sigma_{k}}\right) \frac{\partial k}{\partial x_{i}}\right\} \\
& \text { (Dis. })_{k}=\vec{\rho} \varepsilon \\
& (\text { Pro. })_{\varepsilon}=C_{\varepsilon 1} f_{1}(\text { Pro. })_{k} \frac{\varepsilon}{k} \\
& (\text { Dif. })_{\varepsilon}=\frac{\partial}{\partial x_{i}}\left\{\left(\mu+\frac{\mu_{t}}{\sigma_{\varepsilon}}\right) \frac{\partial \varepsilon}{\partial x_{i}}\right\} \\
& (\text { Dis. })_{\varepsilon}=C_{\varepsilon 2} f_{2}(\text { Dis. })_{k} \frac{\varepsilon}{k} \\
& C_{\varepsilon 1}=1.44, C_{\varepsilon 2}=1.92, \sigma_{k}=1.0, \sigma_{\varepsilon}=1.3
\end{aligned}
$$

ここで, $f_{\mu}, f_{1}, f_{2}$ は, 低レイノルズ数効果を反映する ために設けられたモデル関数であり, Launder-Spalding の高レイノルズ数形標準モデル(8) では

$$
f_{\mu}=f_{1}=f_{2}=1
$$

である。

壁面近傍の分子粘性が支配的な領域における乱れ挙 動の補正として, Lam-Bremhorst モデル(9)ではこれ らの関数を乱れの強さを表す無次元量 $R_{t}\left(=\bar{\rho} k^{2} / \mu \varepsilon\right)$ と，壁からの距離を表す無次元量 $R_{y}(=\bar{\rho} \sqrt{k} y / \mu)$ を用 いて以下のように表現している。 
$f_{\mu}=\left\{1-\exp \left[-0.0165 R_{y}\right]\right\}^{2}\left(1+20.5 / R_{t}\right)$

$f_{1}=1+\left(0.05 / f_{\mu}\right)^{3}$

$f_{2}=1-\exp \left[-R_{t}^{2}\right]$

このモデルは乱れの壁面漸近挙動こそ満たしていない ものの, その安定性より工学上広く用いられている.

最も最近提案された低レイノルズ数形 $k-\varepsilon$ モデル として, Shimada-Nagano モデル(10)を取り上げる. このモデルは, 平均速度を直接含む代表時間スケール $R_{U}$ と乱流レイノルズ数 $R_{t}$ との重み付き線形和によ つて形成された新たなパラメータ $R$ を用いてモデル の構築がなされている。

$$
R=R_{U}+\gamma R_{t} \cdots
$$

ここで、, $\gamma$ は重みパラメータであり，平均場の渦がも つ時間スケール $\tau_{U}$ と散逸渦のもつ時間スケール $\tau_{\eta}$ の 比, ならびにモデル関数 $f_{\gamma}$ にって以下のように関 係づけられる。

$$
\begin{aligned}
& \gamma=f_{\gamma} \frac{\tau_{\eta}}{\tau_{U}} \\
& f_{\gamma}=\left(1-\exp \left[-\left(R_{t} / 200\right)^{3}\right]\right) \times 10^{3} \\
& \tau_{U}=\left(\frac{1}{2} S_{i j} S_{i j}\right)^{-1 / 2} \\
& \tau_{\eta}=\sqrt{\mu / \bar{\rho} \varepsilon}
\end{aligned}
$$

また，モデル関数は以下の形で提案されている。

$$
f_{\mu}=\left(1-f_{w}\right)\left\{1+\frac{50}{R_{t}} \exp \left[-\left(R_{t} / 400\right)^{2}\right]\right\}
$$

$$
f_{1}=1
$$

$$
f_{2}=\left\{1-0.3 \exp \left[-\left(\frac{R_{t}}{6.5}\right)^{2}\right]\right\}
$$$$
\times\left\{1-\exp \left[-\frac{2}{3} R^{1 / 4}\right]\right\}^{2}
$$

Shimada-Nagano モデルでは, これらのモデル関数 を用いると同時に, 乱流運動エネルギーの壁面近傍に おける強い粘性散逸効果を反映させるため, $\varepsilon$ 輸送方 程式有辺に新たな項 $(V i s .)_{\varepsilon}$ が付加される.

$$
(V i s .)_{\varepsilon}=f_{w} \frac{\mu \mu_{t}}{\bar{\rho}}\left(\frac{\partial^{2} \tilde{u}_{i}}{\partial x_{j} \partial x_{k}}\right)^{2}
$$

また，モデル定数も修正され，次のように与えられる。

$$
\begin{aligned}
& C_{\varepsilon 1}=1.45, C_{\varepsilon 2}=1.9, \sigma_{k}=\frac{1.2}{f_{t}}, \sigma_{\varepsilon}=\frac{1.3}{f_{t}} \\
& f_{w}=\exp \left[-R^{3 / 4} / 4500\right] \\
& f_{t}=1+20 \exp \left[-R_{t} / 30\right]
\end{aligned}
$$

Shimada-Nagano モデルは壁面漸近挙動を完全に 満たして抢り，また，低レイノルズ効果を反映させる ためのパラメータに壁面からの距離を用いないという
点において, 複雑形状流れ場への適用に有利であると いえよう。

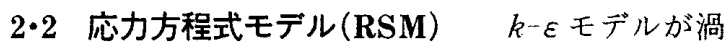
粘性と平均ひずみ速度よりレイノルズ応力を求めるの に対し，RSM はレイノルズ応力自身の輸送方程式を 直接解く手法である. それゆえ, 解くべき方程式の数

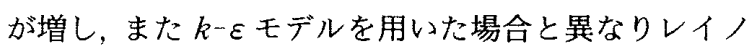
ルズ応力が必ず拡散的に㗢くとは限らないのでスキー ムが渦粘性モデルと比べて不安定であり，計算コスト がかなり上昇する。このため, 圧縮性分野における複 雑な流れ場構造への RSM の適用はほとんど例を見な い.しかしながら, 非圧縮分野では, 渦粘性モデルで の再現が困難な流れに対しても，より正確な解を得る ことが可能であるという報告がされており，本研究の 対象場に対しても解の改善が期待できる.

平均流に密度加重平均を施し，代数操作を行うと， 非圧縮性の場合とほほ同様な形のレイノルズ応力なら びにとの輸送方程式が導かれる。

$$
\begin{aligned}
& \frac{\overline{D \rho_{i}^{\prime \prime} u_{j}^{\prime \prime}}}{D t}=P_{i j}-D_{i j}+\phi_{i j}+T_{i j}+M_{i j} \\
& \frac{D \bar{\rho} \varepsilon}{D t}=P_{\varepsilon}-D_{\varepsilon}+T_{\varepsilon}+M_{\varepsilon} \cdots \cdots \cdots \cdots
\end{aligned}
$$

$P, D, T, M$ はそれぞれ生産, 散逸, 乱流昖散, 分子粘 性拡散を示す項であり，またレイノルズ応力の輸送 方程式中のみ現れる $\phi$ は再分配項と呼ばれ，レイノル ズ㐫力同士のエネルギーの交換を担っている. Gibson-Launder の高レイノルズ数形標準モデル(11) の場 合, 各項は以下のようにモデル化される.

$$
\begin{aligned}
& P_{i, j}=-\left(\overline{\rho u_{i}^{\prime \prime} u_{k}^{\prime \prime}} \frac{\partial \tilde{u}_{j}}{\partial x_{k}}+\overline{\rho u_{j}^{\prime \prime} u_{k}^{\prime \prime}} \frac{\partial \tilde{u}_{i}}{\partial x_{k}}\right) \\
& D_{i j}=\frac{2}{3} \bar{\rho} \varepsilon \delta_{i j} \\
& T_{i j}=\frac{\partial}{\partial x_{k}}\left(C_{s} \frac{k}{\varepsilon} \widetilde{\rho u_{k}^{\prime \prime} u_{i}^{\prime \prime}} \frac{\partial u_{i}^{\prime \prime} u_{j}^{\prime \prime}}{\partial x_{i}}\right) \\
& M_{i j}=\frac{\partial}{\partial x_{k}}\left(\mu \frac{\partial \widetilde{u}_{i}^{\prime \prime} u_{j}^{\prime \prime}}{\partial x_{k}}\right) \\
& P_{\varepsilon}=C_{\varepsilon 1} \frac{\varepsilon}{k}\left(\frac{1}{2} P_{k k}\right) \\
& D_{\varepsilon}=C_{\varepsilon 2} \bar{\rho} \frac{\varepsilon \tilde{\varepsilon}}{k} \\
& T_{\varepsilon}=\frac{\partial}{\partial x_{k}}\left(C_{\varepsilon} \frac{k}{\varepsilon} \overline{\rho u_{k}^{\prime \prime} u_{\iota}^{\prime \prime}} \frac{\partial \varepsilon}{\partial x_{l}}\right) \\
& M_{\varepsilon}=\frac{\partial}{\partial x_{k}}\left(\mu \frac{\partial \varepsilon}{\partial x_{k}}\right) \text {. } \\
& \phi_{i j}=\phi_{(1) i j}+\phi_{(2) i j}+\phi_{(w 1) i j}+\phi_{(w 2) i j} \\
& \phi_{(1) i j}=-C_{1} \frac{\varepsilon}{k}\left(\overline{\rho u_{i}^{\prime \prime} u_{j}^{\prime \prime}}-\frac{2}{3} \bar{\rho} k \delta_{i j}\right) \\
& \phi_{(2) i j}=-C_{2}\left\{P_{i j}-\frac{2}{3}\left(\frac{1}{2} P_{k k}\right) \delta_{i j}\right\}
\end{aligned}
$$




$$
\begin{aligned}
& \phi_{(w 1) i j}=C_{w 1} \frac{\varepsilon}{k}\left\{\overline{\rho u_{k}^{\prime \prime} u \iota_{m}^{\prime \prime}}\left(n_{k} n_{m}\right) \delta_{i j}\right. \\
& \left.-\frac{3}{2} \rho u_{k}^{\prime \prime} u_{i}^{\prime \prime}\left(n_{k} n_{j}\right)-\frac{2}{3} \rho u_{k}^{\prime \prime} u_{j}^{\prime \prime}\left(n_{k} n_{i}\right)\right\} \frac{k^{3 / 2}}{C_{l} \varepsilon d} \\
& \phi_{\left(w^{2}\right) i j}=C_{w 2}\left\{\phi_{(2) k m}\left(n_{k} n_{m}\right) \delta_{i j}-\phi_{(2) k i}\left(n_{k} n_{j}\right)\right. \\
& \left.-\phi_{(2) k j}\left(n_{k} n_{i}\right)\right\} \frac{k^{3 / 2}}{C_{l} \varepsilon d} \\
& C_{s}=0.22, C_{\varepsilon}=0.18, C_{1}=1.8, \\
& C_{2}=0.6, C_{l}=2.5, C_{(w 1)}=0.5 \text {, } \\
& C_{(w 2)}=0.3, C_{\varepsilon 1}=1.44, C_{\varepsilon 2}=1.92
\end{aligned}
$$

一方，低レイノルズ数形モデルの代表である Shima モデル(12) では，レイノルズ応力の非等方テンソル $a_{i j}$ をパラメータとしてモデル定数を以下のように関数化 することにより，壁面近傍の乱れの非等方性の再現が 図られている。

$$
\begin{aligned}
& C_{1}=1+2.58 A A_{2}^{1 / 4}\left\{1-\exp \left[-\left(0.0067 R_{T}\right)^{2}\right]\right\} \\
& C_{2}=0.75 A^{1 / 2} \\
& C_{(w 1)}=-\frac{2}{3} C_{1}+1.67 \\
& C_{(w 2)}=\frac{\max \left[\frac{2}{3}\left(C_{2}-1\right)+0.5,0\right]}{C_{2}} \\
& A=1-\frac{9}{8}\left(A_{2}-A_{3}\right) \\
& A_{2}=a_{i j} a_{j i}, \quad A_{3}=a_{i j} a_{j k} a_{k i} \\
& a_{i j}=\frac{\overline{\rho u_{i}^{\prime \prime} u_{j}^{\prime}}}{\bar{\rho} k}-\frac{2}{3} \delta_{i j}
\end{aligned}
$$

なお, 非圧縮性の分野において, Shima モデルは付 着境界層に対して素晴らしい予測性能を示している が, 大きなはく離を伴う流れ場や庄縮性流れ場に対し て検証された例はなく，その予測性能は明らかではな w.

\section{3. 計 算 手 法}

本研究では, 支配方程式として時間平均 N-S 方程 式を使用し，プログラムの繁雑さを避けるため完全陽

Table 2 Computational conditions

\begin{tabular}{|l||c|c|}
\hline & $\begin{array}{c}\text { Freestream } \\
\text { (air) }\end{array}$ & $\begin{array}{c}\text { Injection Flow } \\
\text { (air) }\end{array}$ \\
\hline Mach Number & 3.75 & 1.0 \\
\hline Velocity $[\mathrm{m} / \mathrm{s}]$ & 666.4 & 322.4 \\
\hline Static Pressure $[\mathrm{Pa}]$ & $1.11 \times 10^{4}$ & $\mathrm{r} \cdot\left(6.34 \times 10^{5}\right)$ \\
\hline Static Temperature $[\mathrm{K}]$ & 78.4 & 249.2 \\
\hline Density $\left[\mathrm{Kg} / \mathrm{m}^{3}\right]$ & 0.493 & $\mathrm{r} \times 8.57$ \\
\hline Molecular Viscosity [Pa $\cdot \mathrm{s}]$ & $5.29 \times 10^{-6}$ & $1.55 \times 10^{-5}$ \\
\hline
\end{tabular}

$r=[$ [njection Total Pressure] / [Freestream Total Pressure]
解法にて定常解計算を行った。時間進行法としては， 計算精度ならびに安定性を考虑して 5 段階ルンゲ・ク ッ夕法を使用し，計算の高速化のため局所時間刻法を 採用した。空間差分は，す心゙ての物理変数に対し，対 流項にHarten-Yee(1987)の二次精度風上形 TVD ス キームを，その他の項に二次精度中心差分を用いてい る.

収束条件は，計算で使用するすべての変数に対して 考慮され，それらの残差が一様に初期残差の $10^{-6}$ 末 満となった時点で収束解と判断し, 計算を終了させ た.

本計算の条件はすべて Aso ら(7) の実験に基づいて いる。これは流れ場構造の三次元性を抑えるために， 空力フェンスを用いて行われた実験であり，二次元計 算との比較には最適であると考えられる。実験では二 次流れガスに窒素が用いられているが, 窒素の物性值 は空気とほほ同様であるため, 本研究では主流/二次 流れともに空気と仮定して計算を行うこととした。計 算条件を表 2 に示寸。ここで，rは主流全厓により正 規化されたインゼクション全压比であり， 0.077 0.46で六と拀りに変化させて話算を実行し， 実験倠とり比較を行う。

計算領域は主流方向に $150 \mathrm{~mm}$, 壁面垂直方向に 75 $\mathrm{mm}$ とし, $1 \mathrm{~mm}$ 幅のインゼクションは計算領域入口 より $70 \mathrm{~mm}$ 地点の壁面上に設置した。この領域に対 し，高レイノルズ数形モデル計算用と低レイノルズ数 形モデル計算用の二つの言算格子が用意された。それ ぞれの格子数は $97 \times 60$ および $97 \times 88$ である，例とし て, 高レイノルズ数形計算用の格子を図 2 に示す。雨 格子ともに格子点は壁面付近とインゼクション付近に 集中させられ、これによりインゼクション流入断面内 に 16 格子点を与えることが可能となっている。また， 高レイノルズ数形計算に扔ける壁面第 1 格子点の $y^{+}$ は流入面で約 20 , 低レイノルズ数形計算では粘性底層 内 $\left(y^{+}<5\right)$ に約 5 格子点が含まれていた。

初期物理量分布の決定は, 以下の上うに行ってい

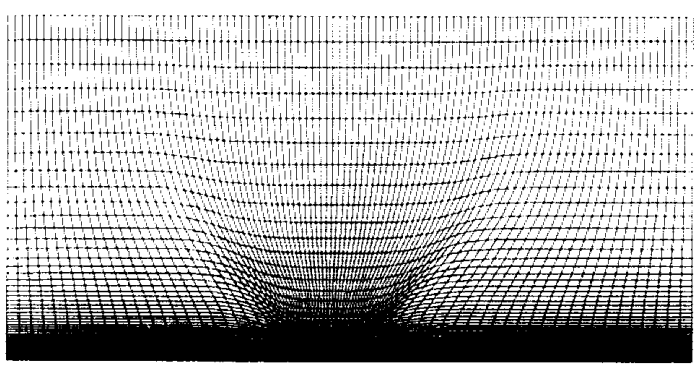

Fig. 2 Computational grid 
る。まず，付着境界層において高い再現性を有する Shima モデルを用いて超音速平板境界層計算を行い, この結果をすべてのケースに対して主流側の分布とし て採用した、インゼクション部に対しては, インゼク ション流を完全に発達したチャネル乱流と仮定し, 主 流側と同様 Shima モデルによる予備計算結果からす べての初期分布を与えている.

境界条件は以下のとおりである，流入面となる計算 領域左面とインゼクション面では流れが超音速である ため, 全変数を固定した. 計算領域右面と上面では, 面法線方向こう配が零となる外挿により物理量を定め た。また, 壁面境界は滑りなし断熱壁を仮定し, 垂直 方向温度こう配を零で与え, 乱れ成分に対しては, 高 レイノルズ数形計算では壁法則を用いて, 低レイノル ズ数形計算では $k=0, \tilde{\varepsilon}=0$ の関係を用いて乱机成分 の設定を行った。

\section{4. 結 果と考察}

典型的な計算結果として, 図 3 に静圧分布とインゼ クション付近の速度ベクトルを示す. 静圧分布には, インゼクション出口付近に Barrel shock, Mach disk, その上方に Bow shock, 前方はく離に伴う Separa-

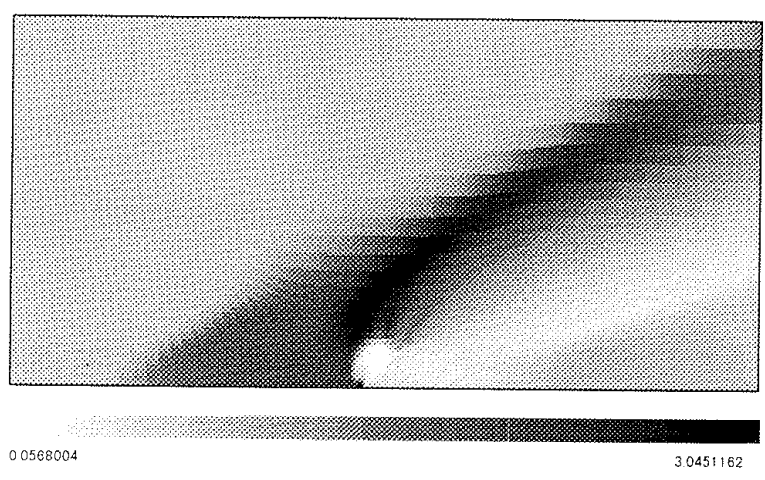

(a) Static pressure contour

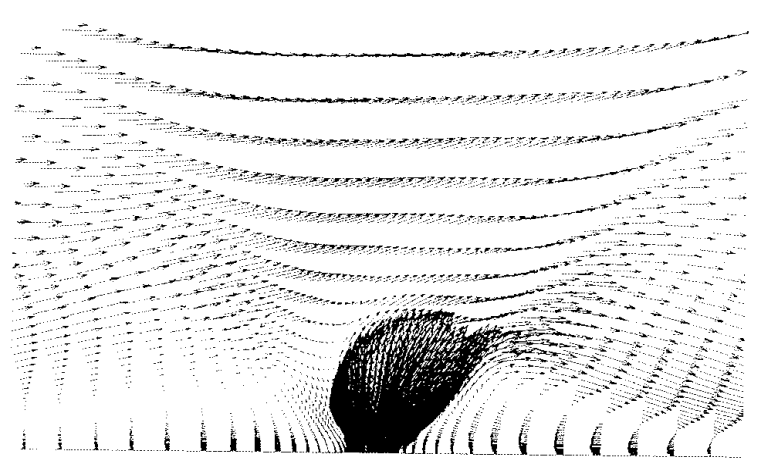

(b) Velocity vectors (Vicinity of injecton)

Fig. 3 Typical computational results (Gibson-Launder Model, Injection pressure ratio $=0.46$ ) tion shock, インゼクション後方に Expansion fan, Recompression shock などが再現されており, また速 度分布よりインゼクション前/後部の再循環領域が確 認できる. 図 1 との比較により, 本計算が定性的に妥 当な解を与えていることが明らかである.

インゼクション全圧比の変化に対する流れ場構造の 変化を等マッ八数線図の形で図 4 に示す.インゼクシ ヨン全圧比が増すに伴い流れ場構造も相似的に拡大し ており，本流れ場がインゼクション全压によって支配 されている様子が見うけられ，実験での知見と一致し ている.

インゼクション全圧比に対する壁面全圧分布を図 5 に示す．まずインゼクション後方領域に着目すると, すべてのインゼクション全压比に対してモデルごとの 大きな差は見られず,この領域はモデルの影響を受け

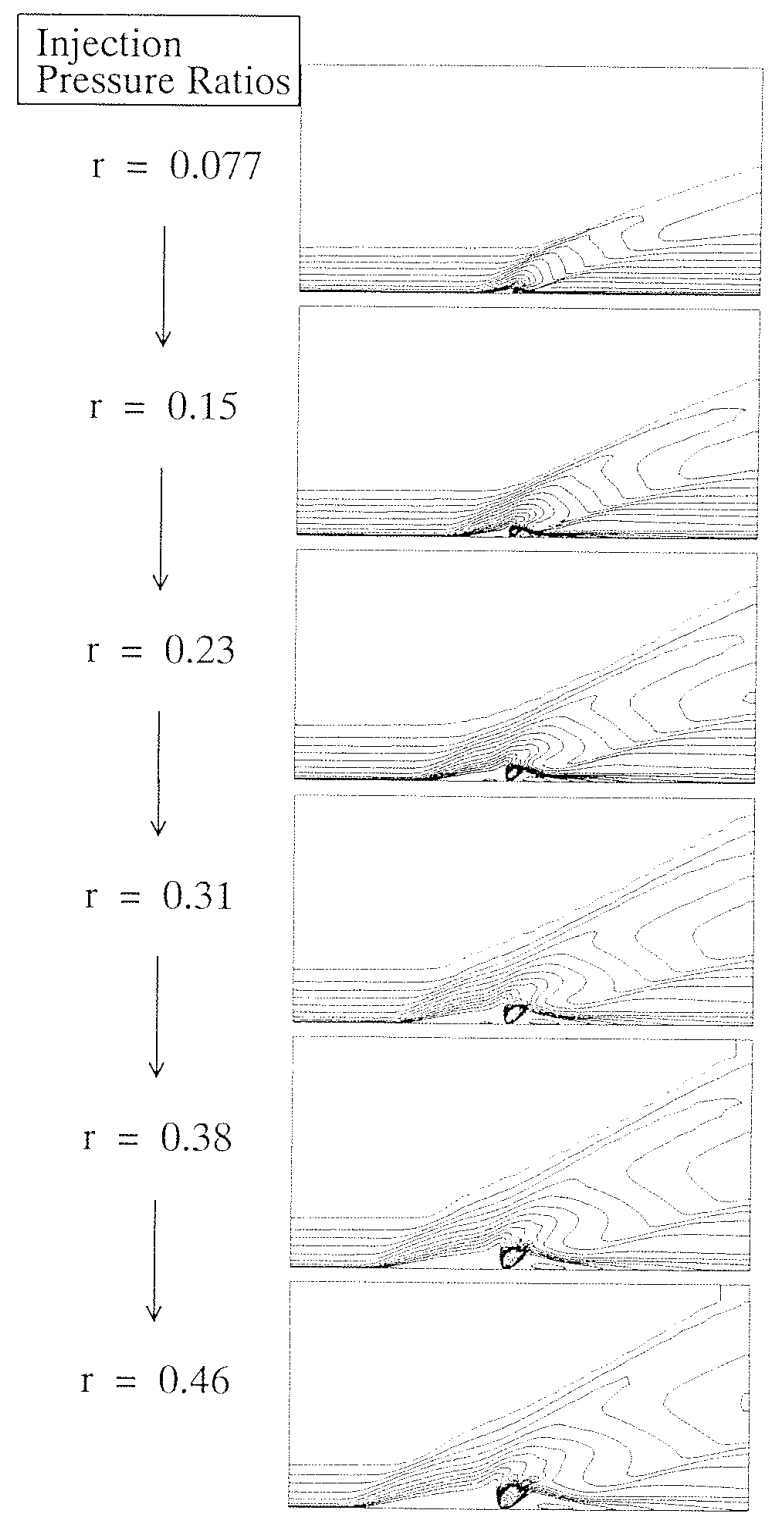

Fig. 4 Mach number contours for different injection pressure ratios 


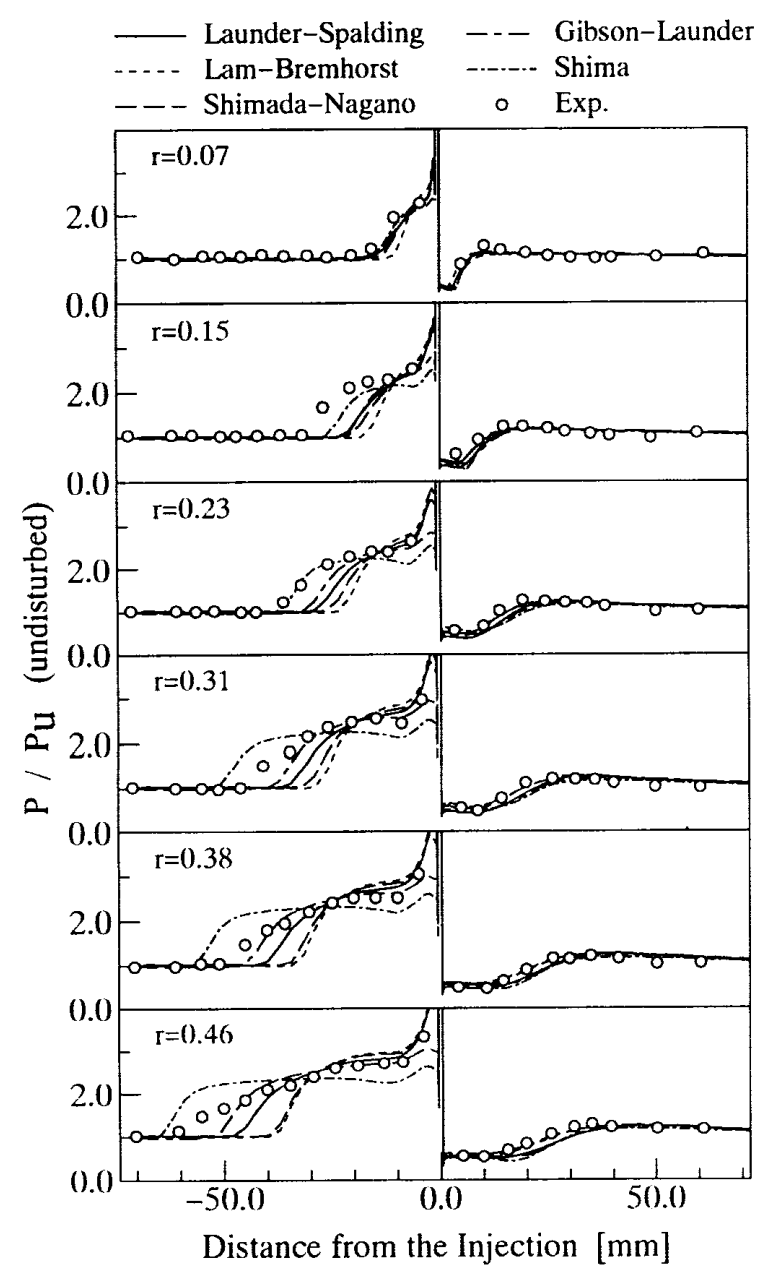

Fig. 5 Surface pressure distributions for different injection pressure ratios

にくいことが明らかである。これに対して、インゼク ション前方の压力上舁領域における全王分布には，特 に高いインゼクション全圧比においてモデルごとの差 が顕著に現れており，モデルの予測性能がこの領域に より強く反映されることがわかる。守べての全压比を 通じて, 予測さ机たはく離長さは, Shima, GibsonLaunder, Launder-Spalding, Shimada-Nagano, Lam-Bremhorst モデルの頌になっている.

これらのことをより明確にするため，モデル性能の 差が最も影著に現れた全圧比 0.46 に対するインゼク ション近傍の流れ場構造を図 6〜8に示す. 図 6 は乱 流エネルギー $k$ の分布であり，インゼクション前/後 方領域ともに, Shima モデルの結果が乱流量を他のモ デルよりもかなり過小評価していることがわかる。イ ンゼクション下方領域に扔いて Shima モデルが乱流 量を過小予測しているにもかかわらず，この領域での 圧力分布には他のモデルとの大きな違いが見られない ことより，この領域が乱れの影響を受けにくい領域で

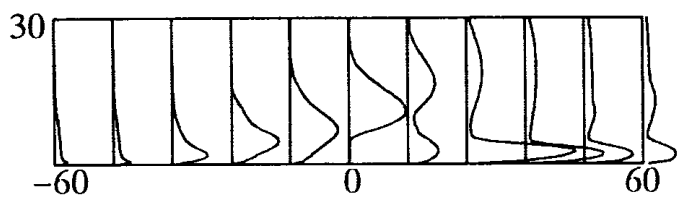

(a) Launder-Spalding

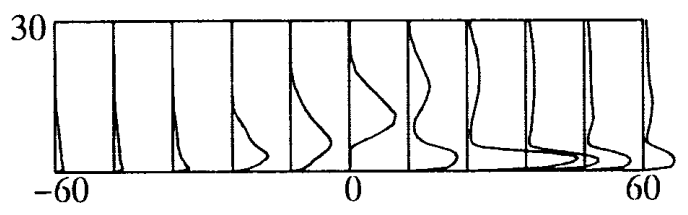

(b) Lam-Bremhorst

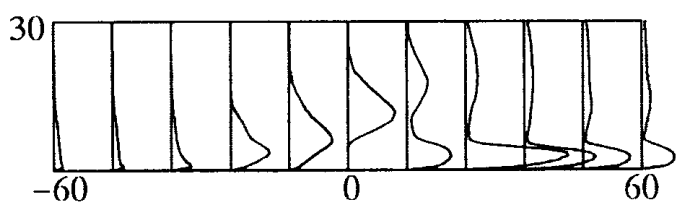

(c) Shimada-Nagano

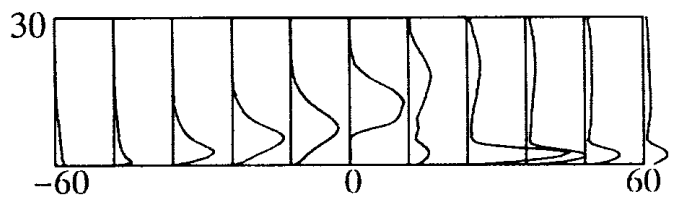

(d) Gibson Launder

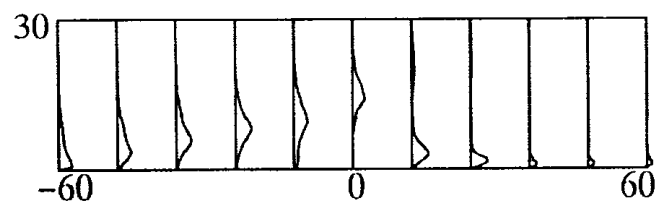

(e) Shima

Fig. 6 Kinetic energy distributions aroud the injection

あることが確認できる，また, Shima モデルは, 乱れ の過小予測によりインゼクション前方はく離渦の大き さを過大予測し, 压力上昇領域の拡大と上昇值の低下 につながったものと考えられる。

インゼクション付近の衝撃波システムを明らかにす るため, 図 7 には等マッ八数線図が示されており,こ れらの構造を形成する中間的マッ八数 $(M=2.5)$ を結 ぶことによって，この構造の輪郭を表したのが図 8 で ある.図 7,8 から, 上流側の Barrel shock 形状にモ デルごとの大きな隔たりが確認され，乱流モデルの違 いによる流れ場構造の変化は, 特にインゼクション前 方の構造と密接に関係していることがわかる。これら の構造はインゼクション出口付近の全压に支配されて おり，前方渦の形状に伴う Separation shock の傾き の違いが,インゼクション前方全压を変化させるもの と考えられる。したがって，インゼクション前方領域 


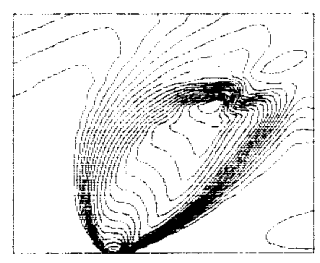

(a) Launder-Spalding

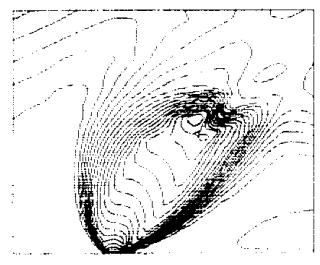

(b) Lam Bremhorst

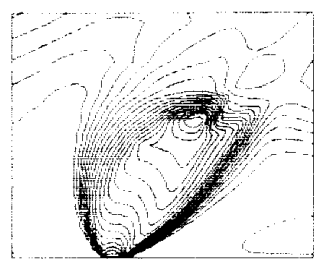

(c) Shimada Nagano

Fig. 7 Mach number contours in the vicinity of injection

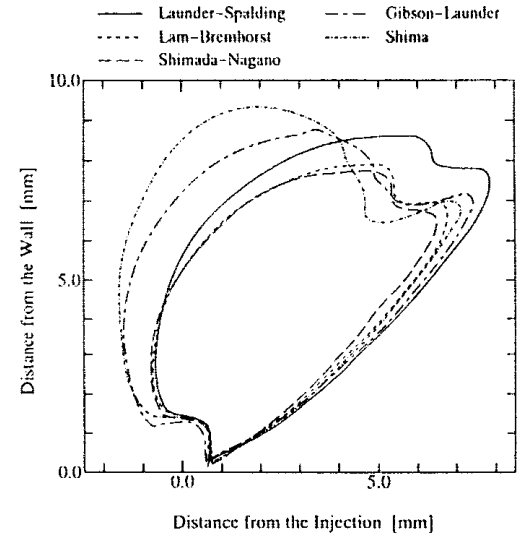

Fig. 8 Comparison of shock systems with each model

において Barrel shock とはく離泡は互いに強く干涉 しあっており，そのはく離泡がモデル性能に強く依存 寸るため，モデルによる構造の違いがこの領域に顕著 に現れるのであろう。このことは逆に，流入する境界 層の乱れ状態や衝撃波境界層丁涉によって生じる乱れ を変えることによって，Barrel shock の構造を制御で きる可能性があることを示唆している。

図 9 には，インゼクション全王比と前方はく離長さ の関係が示されている，圧縮効果が比較的小さいと考 えられる小さな全压比に対して，すべての結果は実験 値とよい一致を示し、さらに全压比の増加に伴うはく

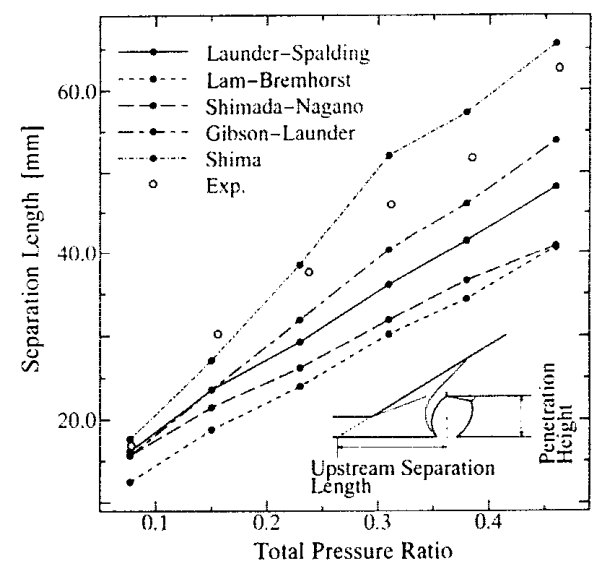

Fig. 9 Change of upstream separation length with the injection pressure ratio

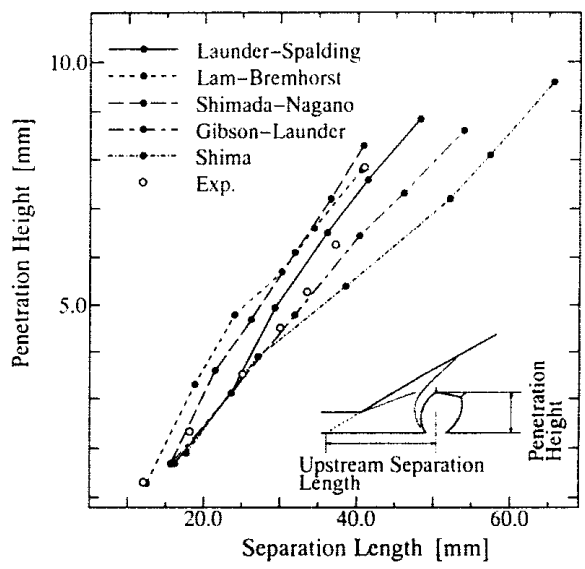

Fig. 10 Correlation between the penetration and the upstream separation length

離長さの直線的な変化は，実験により示された性質を 再現している。しかし，その変化の割合はモデルごと に異なっており，特に高い全圧比において実験值との 差が大きく, Shima モデルを除き，はく離長さを過小 評価する傾向がある。

次に，貫通高さおよび前方はく離長さについて調べ てみる、インゼクションから噴出された二次流れは急 速に膨張しながら上昇し, Mach diskに到達するまで その運動方向を保持する。したがって, 壁面から Mach disk までの距離を流路障害の高さと考えるこ とができるので，これを貫通高さとして定義する，図 10 に貫通高さと前方はく離長さとの関係を示す。ど のモデルによる結果も㬰験值との大きな違いは生じて おらず，図 9 の結果を考虑すると，数値予測では貫通 高さも過少評価されていることが指摘できる。この貫 通高さはインゼクション付近の全压に支配され，その 全压はインゼクション前方のはく離泡に依存している ので、本計算におけるモデル性能はこのはく離領域内 
の全圧を再現する能力と考えることができるであろ う.したがって、乱流モデルを評価するうえで, Compression corner などのより基礎的な研究がさらに重 要な意味ともつと考えられる。

\section{5. 結訔}

5 種類の代表的な乱流モデルを用いて，主流に垂直 な二次噴流を伴う超音速乱流場の数値計算を行い, Aso らの実験データと比較することにより，以下の知 見を得た。

（1）計算を行ったすべてのインゼクション全圧比 に対し，モデル性能は定性的に一様であるが，定量的 な差は全厈比が増すにつれて大きくなる。

（2）インゼクション前方のはく離領域は，使用す る乱流モデルにより違いが顕著に現れることが明らか となった。

（3）インゼクション後方領域の流れ場は乱れにさ ほど依存しておらず，すべての乱流モデルに対し実験 とのよい一致が見られた。

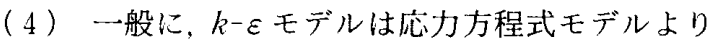
も前方はく離領域を小さく予測し，低レイノルズ数形 モデルでは両者の差が顕著である.

（5）本研究で使用されたすべてのモデルは，工学 上妥当なレベルの定性的再現性を有しているが，実験 との定量的な一致には，圧縮性効果の導入など，上り いっそうの改良が必要である。

\section{文献}

(1) Zukoski, E. E. and Spaid, F. W., Secondary Injection of
Gases into a Supersonic Flow, AIAA J., 2(1964), 1689. 1696.

(2) Spaid, F. W. and Zukoski, E. E., A Study of the Injection of Gaseous Jets from Transverse Slots with Supersonic External Flows, AIAA J., 6(1968), 205-212.

(3) Schetz, J. S., Hawkins, P. F. and Lehan, H., Structure of Highly Under-Expanded Transverse Jets in a Supersonic Stream, AIAA J., 5(1967), 882-884

(4) Hawk, N. E. and Anick, L. J., Tow-Dimensional Secondary Jet Interaction with a Supersonic Stream, $A I A A$ J., 5(1967), 655-660.

(5) Young, C. T. and Barfield, B. F., Viscous Interaction of Sonic Transverse Jets with Supersonic External Flows, AIAA J., 10(1972), 853-854.

(6) King, P. S., Thomas, R. H. and Schetz, J. A., Combined Tangential-Normal Injection into a Supersonic Flow, AIAA Paper, 89-0622(1989).

(7) Aso, S., Okuyama, S., Ando, Y. and Fuzinori, T., Two Dimensional and Three-Dimensional Mixing Flow Fields in Supersonic Flow Induced by Injecter Secondary Flows through Traverse Slot and Circular Noz. zle, AIAA Paper, 93-0489(1993).

(8) Launder, B.E. and Spalding. D. B., The Numerical Computation of Turbulent Flow, Comput. Meth. Appl. Mech. Eng., 3(1974), 261“289.

(9) Lam, C. K. G. and Bremhorst, K. A., A Modified Form of the $k \varepsilon \varepsilon$ Model for Predicting Wall Turbulence, Trans. ASME, J. Fluid Eng., 103(1981), 456 460.

（10）島田昌也・辰野暜尚，被雑乱流技術計算のための乱流玉 デルに関する研究，第11 间 NST シンボジウム講演論文 集, (1996), 1-8.

(11) Gibson, M. M. and Launder, B. E.. Ground Effects on Pressure Fluctuations in the Atmospheric Boundary Layer, J. Fluid Mech., 86(1978), 495511.

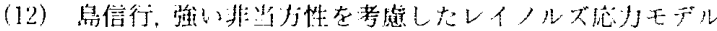

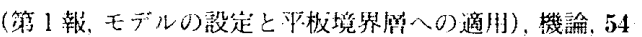
$505, B(1988), 23172324$. 